\title{
SLC1A5 Gene
}

National Cancer Institute

\section{Source}

National Cancer Institute. SLC1A5 Gene. NCI Thesaurus. Code C118925.

This gene is involved in both neutral amino acid transport and retrovirus binding. 